\title{
Collar Rot of Apple Caused by Phytophthora cambivora (Petri) Buism.
}

\author{
Takahito Suzui* and Yoshihiro Hoshino** \\ 鈴井孝仁* ・星野好博** : Phytophthora cambivora (Petri) Buism. \\ によるリンゴ（矮性台木, MM 106）の疫病
}

\begin{abstract}
Collar and root rot of apple (dwarfing rootstock, MM 106) was detected in Yoichi and Niki, Hokkaido, in 1977. Phytophthora sp. was isolated from the diseased trunk under the ground and roots of apple rootstocks. It was identified as $P$. cambivora from the characters of sporangia and sex organs. P. cambivora and $P$. cactorum were isolated from soil near by the diseased trees. One hundred fifty isolates of $P$. cambivora proved to belong to the mating type $\mathrm{A}^{1}$ and 9 isolates to the mating type $\mathrm{A}^{2}$. $P$. cambivora was able to induce collar and root rot in apple (MM 106) by the zoospore inoculation test.

(Received March 22, 1979)
\end{abstract}

\section{Introduction}

Apple dwarfing rootstocks ( $\mathrm{M}$ and $\mathrm{MM}$ series) are spreading for the rationalization of apple cultivation in Japan. Collar rot of size-controlling rootstocks of apple is known to occur universally. Phytophthora fruit rot of apple caused by Phytophthora cactorum had been observed in apple in Japan unlike collar $\operatorname{rot}^{7,11)}$. The symptoms were noted for the first time in apple rootstook MM 106 in orchards in Yoichi and Niki, Hokkaido in 1977 prompting the isolation, identification and some physiological studies of this microorganism.

\section{Materials and Methods}

Phytophthora sp. was isolated from the diseased collar and root of apple rootstock MM 106 (Malus pumila cv. Northern SPY $\times$ M. pumila var. paradisiaca) and from soil in orchard located in Yoichi and Niki in 1977. Selective medium was used for isolation of Phytophthora ${ }^{8}$. Baiting methods, which were used for isolation from soil, consist of modified Grim's method using small pieces of apple leaves ${ }^{3)}$ and trap method of twig or young fruit of apple trees ${ }^{7}$.

Sporangia were formed in the soil suspension after cultivation on cleared $\mathrm{V}-8$ juice agar $(\mathrm{CV}-8 \mathrm{~A})^{12}$ ) at $25 \mathrm{C}$ for 10 days. Sex organs were formed in $\mathrm{CV}-8 \mathrm{~A}$ when pairing took place with compatibility mating types of $\mathrm{P} 746\left(\mathrm{~A}^{1}\right)$ and $\mathrm{P} 635$ $\left(\mathrm{A}^{2}\right)$ isolates from P. cambivora, of $\mathrm{P} 253\left(\mathrm{~A}^{1}\right)$ and $\mathrm{P} 255\left(\mathrm{~A}^{2}\right)$ isolates from $P$. palmivora and of $\mathrm{T} 131\left(\mathrm{~A}^{1}\right)$ and $\mathrm{T} 515\left(\mathrm{~A}^{2}\right)$ isolates from $P$. nicotianae var. parasitica

* Hokkaido National Agricultural Experiment Station, 農林水産省北海道農業試験場 Present address ; Shizuoka Agricultural Experiment Station, 4-27-1 Kita-Ando, Shizuoka 420, Japan 静岡県農業試験場

** Kita 7, Nishi 22, Chuoh-Ku, Sapporo 060, Japan. 
(Culture Collection of Univ. Calif.) at $25 \mathrm{C}$, in the dark for 1 month. For determination of the cardinal temperature and of the fungal growth rate of the isolates, inoculum was transferred to the center of bacto-potato dextrose agar (bacto-PDA) and bacto-corn meal agar (bacto-CMA) and was incubated at temperatures ranging from 3 to $37 \mathrm{C}$ for 11 days. Diameter of colony was measured every day. Layerings of apple tree (MM 106) and nursery plants of Japanese chestnut (Castanea crenata), twigs and leaves of apple tree (MM 106), twigs of sweet chestnut (Castanea sativa), and fruits of apple (starking delicious) were used in inoculation test. Inocula to apple and chestnut nursery plants were mycelia, crushed infected apple fruit and zoospore suspension. Mycelia and crushed infected apple fruit were mixed with soil near the collar and roots of apple layering in pot. In the zoospore inoculation, plants were steeped in the suspension with aeration for $24 \mathrm{hr}$, and the plants were planted in pots with soil sterilized by steam. The plants were kept in greenhouse. Plants wounded by 10 burned needles were prepared in every inoculation test.

\section{Results}

\section{Symptoms}

Diseased plants showed reduced vigor on the whole, and the leaves became smaller than the healthy ones. In early autumn their red coloration became more pronounced, with a dash of purple. They defoliated earlier than the healthy ones. These foliar symptoms were never noticed before the rotting of the rootstock was fairly advanced. Discoloration of cortex and cambium was observed when the bark was stripped off ( 1 in Plate). Occasionally, however, the presence of such rotting was revealed by a moist appearance of the external bark. When the disease advanced, major changes occurred in the rootstock i.e. browing and softening progressing vertically and laterally, girdled the trunk and extended to the root, including the fibrous roots. As the softening advanced, the remaining bark was easily sloughed off from the root ( 2 in Plate). In every case, the lesions did not extend beyond the graft union.

\section{Isolation}

Phytophthora spp. were isolated from 8 specimens of collar, 4 specimens of root rot of apple rootstock, MM 106 and 3 specimens of soil, that were collected from the site of the diseased trees, in Yoichi and Niki apple orchards. Isolation ratio of Phytophthora spp. was 0 to $72 \%$ from collar rot, 2.6 to $16.1 \%$ from root rot and 0 to $94.7 \%$ from soil for specimens used in experiments. Phytophthora spp. could be divided into 2 types, A 84 and A 230 from the appearance of colonies on PDA, CMA and CV-8A media and from the shape of sporangia. Sixty one and nine isolates were collected from collar and root rot respectively, and all of them belonged to

Table 1. Phytophthora spp. isolated from collar and root rot of apple (MM 106) and soil in the vicinity of diseased plants in Yoichi and Niki, Hokkaido

\begin{tabular}{l|c|c|c}
\hline \multicolumn{1}{c|}{ Source } & $\begin{array}{c}\text { No. of Phytophthora } \\
\text { isolated }\end{array}$ & $\begin{array}{c}\text { No. of Phytophthora } \\
\text { A 84 type }\end{array}$ & $\begin{array}{c}\text { No. of Phytophthora } \\
\text { A 230 type }\end{array}$ \\
\hline Collar rot & 61 & 61 & 0 \\
Root rot & 9 & 9 & 0 \\
Soil & 136 & 128 & 8 \\
\hline
\end{tabular}


A 84 type while 128 of 136 isolaets from soil into A 84 type and 8 into A 230 type (Table 1 ).

\section{Identification of isolates}

The description of A 84 isolate collected from collar rot is as follows : Hyphae uniform, av. $5.2 \mu \mathrm{m}$ diam., profuse tough aerial mycelia without coralloid or hyphal swelling as spheroidal inflations. Chlamydospores absent. Sporangiophores proliferating within empty sporangia or simple monochasial sympodium, av. $3.3 \mu \mathrm{m}$ diam. Sporangia formed in aqueous solution, no papilla, ovoid, broad apex, apical thickening slight, $25-65 \times 17-31 \mu \mathrm{m}$, av. $46 \times 25$ $\mu \mathrm{m}, \mathrm{L} / \mathrm{B}$ ratio 1.8 , non-deciduous, exit pore $9.6 \mu \mathrm{m}$ ( 3 and 4 in Plate). Sex organs absent in single strain culture, but present when pairing with an opposite strain of $P$. cambivora, $P$. nicotianae var. parasitica and $P$. palmivora. Oogonia slightly yellow, spherical, av. 37 $\mu \mathrm{m}$, when pairing with $P$. cambivora mating type $\mathrm{A}^{2}$, with protuberance or smooth (5 in Plate). Antheridia amphigynous, bi- and uni-cellular, av. $18 \mu \mathrm{m}$ width, $28 \mu \mathrm{m}$ long when pairing with P. cambivora mating type $\mathrm{A}^{2}$ ( 6 in Plate). Oospores nearly filling, av. $33 \mu \mathrm{m}$ when pairing with an opposite strain, $P$. cambivora mating type $\mathrm{A}^{2}$. Culture uniform and fluffy.

The surface structure of oogonia of the isolates and its appearance differs depending on pairing of opposite mating type or of compatibility type of other species. When A 84 isolate paired with A 265 isolate the surface of oogonial wall showed a protuberance $(18 \%)$ or was smooth (81 \%), but when paired with $P$. palmivora oogonia the surface was only smooth (Table 2). Haasis et $a l .{ }^{4)}$ also reported that in the case of intraspecific pairing, protuberant and smooth oogonial wall occurred in varying proportion. Appearance of uniand bi-cellular antheridia as reported by Ho et al.5) could be confirmed and the proportion of the two kinds of an-

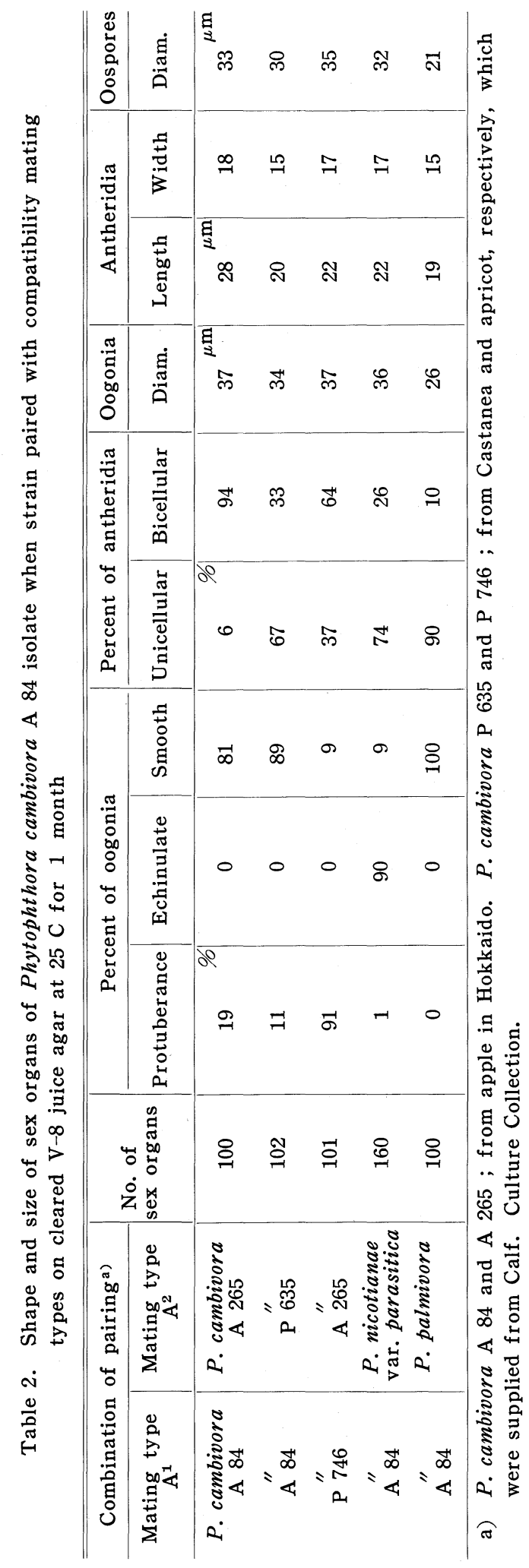


theridia also varied depending on pairing of opposite mating types (Table 2). Size of oogonia, antheridia and oospores was somehow in conformity with pairing of mating $\mathrm{A}^{1}$ and $\mathrm{A}^{2}$ types (Table 2). Growth curve of $\mathrm{A} 84$ isolates at different temperatures 5 days after inoculation on bacto-PDA and bacto-CMA is shown in Fig. 1. Minimum, optimum and maximum temperatures for A 84 isolate growth on bacto-PDA were $3,22-24$ and $32 \mathrm{C}$, respectively. On bacto-CMA, optimum temperature was 25 $\mathrm{C}$ for fungal growth of $\mathrm{A} 84$ isolate, and minimum and maximum temperatures were the same as on bacto-PDA. Growth rate of the isolate on bacto-PDA and on bactoCMA was 5.0 and $5.8 \mathrm{~mm}$ a day at 24 and $25 \mathrm{C}$, respectively.

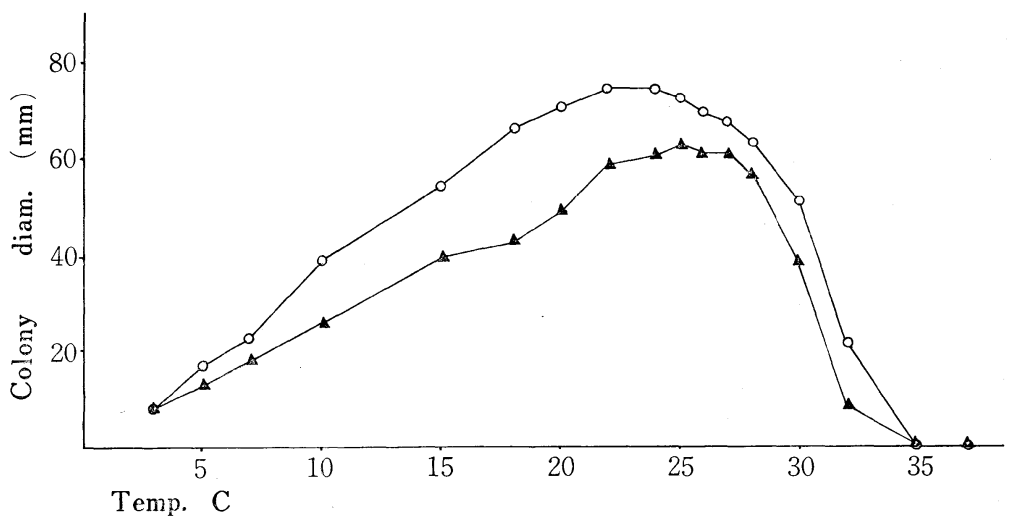

Fig. 1. Hyphal growth of Phytophthora A 84 isolate at varying temperatures 5 days after transfer on bacto-PDA $(\mathrm{O}-$

) and on bacto-CMA ( $\mathbf{A}-\mathbf{A})$.

From the above mentioned results, the characteristics of A 84 were compared with those of $P$. cambivor $a^{10)}$ as shown in Table 3 . P. cambivora is characterized by the presence of a protuberance on the wall surface in oogonia and of bi-cellular antheridia. A 84 isolate showed the same characteristics and other experimental results were almost in agreement with the description of $P$. cambivora. A 84 isolate was identified as P. cambivora (Petri) Buism. Morphological characters of A 27, A 265 and other A 84 type isolates were the same as those of A 84 isolate. $P$. cambivora A 84 (mating type $\mathrm{A}^{1}$ ) was deposited at the Institute of Fermentation Organization (IFO 30471) and at the Commonwealth Mycological Institute (IMI 229178), and $P$. cambivora A 265 isolate (mating type $\mathrm{A}^{2}$ ) was also deposited at IFO (IFO 30472).

The description of A 230 isolate collected from soil is as follows : Hyphae av. 4.1 $\mu \mathrm{m}$ diam., without characteristic hyphal swellings. Chlamydospores seldom formed, spherical, 30-36 $\mu \mathrm{m}$ diam. Sporangiophores produce simple monochasial sympodium, av. $1.8 \mu \mathrm{m}$ diam. Sporangia abundant on solid media (PDA, CMA, OMA, CV-8A), subglobose, broadly-ellipsoidal, obpyriform with a conspicuous hemispherical papilla up to $5 \mu \mathrm{m}$, mostly $22-32 \times 17-27 \mu \mathrm{m}$, av. $27 \times 22 \mu \mathrm{m}, \mathrm{L} / \mathrm{B}$ ratio 1.2 , deciduous with a pedicel (up to $4 \mu \mathrm{m}$ ). Sex organs abundant on solid media in single strain culture. Oogonia spherical, 22-37 $\mu \mathrm{m}$ diam., av. $31 \mu \mathrm{m}$, wall thin, slightly yellow and smooth. Antheridia paragynous, irregularly club-shaped, av. $15 \times 10 \mu \mathrm{m}$, and monoclinous. Oospores nearly filling, spherical, 19-31 $\mu \mathrm{m}$, av. $26 \mu \mathrm{m}$. Culture uniform, slightly aerial mycelia.

Minimum, optimum and maximum temperatures for growth of A 230 isolate were below 3,27 and $32 \mathrm{C}$ on bacto-PDA respectively, and below 3,28 and $32 \mathrm{C}$ on bacto- 
Table 3. Comparison of the main characters of Phytophthora A 84 isolate collected from collar rot of apple caused by $P$. cambivora

\begin{tabular}{|c|c|c|}
\hline Item & P. cambivora ${ }^{\mathrm{a})}$ & Phytophthora A 84 isolate ${ }^{\text {b) }}$ \\
\hline Hyphae : Angular swelling & Absent & Absent \\
\hline Sporangia : Size & $55-65 \times 40-45 \mu \mathrm{m}$ & $46 \times 25 \mu \mathrm{m}$ \\
\hline L/B ratio & 1.4 & 1.8 \\
\hline Vacuole & Without & Without \\
\hline Apical thickening & Slight & Slight \\
\hline Oogonia : Surface & Protuberances & Protuberances or smooth \\
\hline Size & $43 \mu \mathrm{m}$ & $37 \mu \mathrm{m}$ \\
\hline Antheridia : Cell & Bi-, uni-cellular & Bi-, uni-cellular \\
\hline Size & $25 \mu \mathrm{m}$ long & $28 \mu \mathrm{m}$ long \\
\hline Oospores : Size & $36 \mu \mathrm{m}$ & $33 \mu \mathrm{m}$ \\
\hline $\begin{array}{r}\text { Hyphal growth temp.: } \text { Min. } \\
\text { Opt. } \\
\text { Max. }\end{array}$ & $\begin{array}{l}\text { About } 2 \mathrm{C} \\
22-24 \mathrm{C} \\
32 \mathrm{C}\end{array}$ & $\begin{array}{l}\text { Under } 3 \mathrm{C} \\
24-25 \mathrm{C} \\
32 \mathrm{C}\end{array}$ \\
\hline
\end{tabular}

a) ; Waterhouse et $a l .^{10}$ )

b) ; Sporangia formed on apple fruit. Sex organs were formed when strain paired with Phytophthora A 265 isolate from collar rot of apple.

CMA respectively. Growth rate of $\mathrm{A} 230$ isolate at $27 \mathrm{C}$ was $3.5 \mathrm{~mm}$ a day on bacto-PDA and $5.6 \mathrm{~mm}$ on bacto-CMA, respectively. From the above mentioned results, A 230 isolate was identified as $P$. cactorum (Leb. \& Cohn) Schroet. $P$. cactorum, A 230 isolate was deposited at IFO (IFO 30474).

\section{Mating types of isolates}

Mating types of 159 isolates of $P$. cambivora collected from infected tissues of collar, root rot and soil were determined by pairing with compativility mating type. One hundred fifty isolates belonged to the mating type $\mathrm{A}^{1}$ and 9 isolates to the mating $\mathrm{A}^{2}$ (Table 4). The mating type $\mathrm{A}^{1}$ was dominant in isolates but both types were recovered from all isolates from portions of collar, root and soil, and from the same diseased trees.
Table 4. Mating types of Phytophthora cambivora isolated from collar and root rot of apple (MM 106) and soil in Hokkaido

\begin{tabular}{l|c|c}
\hline \hline \multirow{2}{*}{ Source } & \multicolumn{2}{|l}{$\begin{array}{l}\text { Number of Phytophthora cambivo- } \\
\text { ra isolates }\end{array}$} \\
\cline { 2 - 3 } & Mating type $\mathrm{A}^{1}$ & Mating type $\mathrm{A}^{2}$ \\
\hline Collar rot & 50 & 6 \\
Root rot & 7 & 2 \\
Soil & 93 & 1 \\
\hline Total & 150 & 9 \\
\hline
\end{tabular}

\section{Pathogenicity to apple and chestnut trees}

Following the inoculation test with $P$. cambivora A 84 and A 27 isolates and with $P$. cactorum A 221 and A 230 isolates, appearance of symptoms, on young apple fruits (starking delicious), detached leaves (MM 106) and twigs (MM 106) of apple was only recognized in the case of wounded specimens in all of the inoculations except in the inoculation of unwounded leaves with $P$. cactorum A 230 isolate. When infected apple fruit was used as inoculum, $P$. cambivora A 84 and $P$. cactorum A 230 produced symptoms of collar rot on the trunk and root rot in case of inoculation through wounding and pathogen was recovered from these diseased tissues. In the inoculation without wounding, however, no symptoms appeared in both inocula. Also mycelia inoculation failed to give rise to collar rot in any trees following with and 
without wounding treatments. P. cambivora A 27 isolate was used for zoospore inoculation and for abundant production of zoospores of this isolate. The results of zoospore inoculation by $P$. cambivora A 27 and $P$. cactorum A 221 and A 230 are shown in Table 5. Symptoms of collar rot appeared in the case of wounding and when pouring method of zoospore suspension of P. cambivora A 27 was applied without wounding. A 27 isolate was recovered from infected trunk and roots (Table 5). Symptoms did not appear on either trunk or roots in all experimental plots of $P$. cactorum following zoospore inoculation.

Table 5. Pathogenicity of Phytophthora cambivora (A 27 isolate) and of P. cactorum (A 221 and A 230 isolates) in apple layerings (MM 106)

\begin{tabular}{|c|c|c|c|c|c|c|c|}
\hline \multirow{2}{*}{ Inoculum } & \multirow{2}{*}{ Isolate } & \multirow{2}{*}{ Inoculation method } & \multirow{2}{*}{$\begin{array}{c}\text { Treatment } \\
\text { in } \\
\text { layering }\end{array}$} & \multicolumn{2}{|c|}{$\begin{array}{l}\text { Appearance of } \\
\text { symptomse) }\end{array}$} & \multicolumn{2}{|c|}{$\begin{array}{c}\text { Reisolation of } \\
\text { pathogen }\end{array}$} \\
\hline & & & & $\begin{array}{l}\text { Collar } \\
\text { rot }\end{array}$ & $\begin{array}{l}\text { Root } \\
\text { rot }\end{array}$ & $\begin{array}{l}\text { Collar } \\
\text { rot }\end{array}$ & $\begin{array}{l}\text { Root } \\
\text { rot }\end{array}$ \\
\hline $\begin{array}{l}\text { Phytophthora } \\
\text { cambivora }\end{array}$ & A 27 & $\begin{array}{l}\text { Steeped in zoospore } \\
\text { suspension a) }\end{array}$ & Wounded ${ }^{\mathrm{d}}$ ) & + & \pm & + & + \\
\hline do. & do. & do. & Unwounded & \pm & \pm & - & - \\
\hline do. & do. & $\begin{array}{l}\text { Pouring zoospore } \\
\left.\text { suspension }{ }^{b}\right)\end{array}$ & Unwounded & + & \pm & + & + \\
\hline Control & - & Steeped in water $\left.{ }^{c}\right)$ & Wounded & - & \pm & - & - \\
\hline do. & - & do. & Unwounded & - & \pm & - & - \\
\hline P. cactorum & A 221 & $\begin{array}{l}\text { Steeped in zoospore } \\
\text { suspension }\end{array}$ & Wounded & - & \pm & - & - \\
\hline do. & do. & do. & Unwounded & \pm & \pm & - & - \\
\hline do. & A 230 & do. & Wounded & - & \pm & - & - \\
\hline do. & do. & do. & Unwounded & - & \pm & - & - \\
\hline Control & - & Steeped in water & Wounded & - & \pm & - & - \\
\hline do. & - & do. & Unwounded & - & \pm & - & - \\
\hline
\end{tabular}

a) : Layerings were steeped in the zoospore suspension for $24 \mathrm{hr}$.

b) : Zoospore suspension was poured into the soil.

c) : Layerings were steeped in water for $24 \mathrm{hr}$.

d) : Wounded by 10 burned sewing needles.

e) : +; Appearance of symptoms of collar or root rot.

\pm ; Color change brown to light brown.

-; No symptoms appeared.

Observation 60 days after inoculation.

Inoculation test of $P$. cambivora A 27 to nursery plants of Japanese chestnut was carried out by applying zoospore pouring method into the soil in wounded and unwounded plants. Symptoms of collar rot appeared on the wounded trunk of trees and inoculum was recovered from the diseased trunk and roots. In the plot of plants inoculated without wounding foliage wilt was observed in 2 out of 3 chestnut plants, and inoculum was recovered from the trunk. In the inoculation test of $P$. cambivora A 27 to the detached twigs of sweet chestnut (Castanea sativa), symptoms appeared both in wounded and unwounded twigs by agar disk method, and a high percentage of inoculum was reisolated from the diseased tissues. 


\section{Conclusion}

In the present study, only $P$. cambivora was isolated from infected tissues of collar and root rot of apple (MM 106) rootstock. Both P. cambivora and P. cactorum, however, were isolated from soil around the diseased apple trees. Although $P$. cactorum has been reported to be the main pathogen of collar rot of apple rootstock by most authors ${ }^{1)}$, in the present study this species could not be isolated from the diseased plants. P. cambivora is known as one of the pathogen of ink disease, of chestnut and basal canker of Norway maple ${ }^{10)}$. In addition, many host plants have been reported ${ }^{2)}$. Recently Mircetich et al.9) described the same disease of apple caused by $P$. cambivora. More recently, Julis et al. ${ }^{6)}$ reported that $P$. cambivora as well as $P$ cactorum could be isolated from $\mathrm{M}$ and $\mathrm{MM}$ rootstocks sampled from various areas in northern America. This is the first report demonstrating that $P$. cambivora is associated with collar and root rot of apple in Japan. The writers propose that the disease be designated as Ekibyo in the same Japanese name with fruit rot caused by $P$. cactorum.

The writers express their sincere gratitude to Dr. G. A. Zentmyer, Univ. Calif. Riverside, Dr. T. Watanabe, Meiji Seika Co. LTD, Mr. S. Hosogai, Hokkaido Pref. Cent. Agric. Exp. Stn., Dr. K. Takanashi, Nat. Fruit Tree Exp. Stn., and Mr. H. Kuroda, Kita-Shiribeshi Agric. Ext. Stn., for supplying them with authentic $P$. cambivora, chemicals, apple layerings, chestnut plants and collection of specimens.

\section{Literature cited}

1. Anderson, H. W. (1956). Diseases of fruit crops. McGraw-Hill Book Co. Inc., NY. pp. 119124.

2. Crandall, B. S. (1936). Pl. Dis. Reptr. $20: 202-204$.

3. Grim, G. R. and Alexander, A. F. (1973). Phytopathology $63: 540-541$.

4. Haasis, F. A., Marx, D. H. and Nelson, R. R. (1966). J. Elisha Mitchell Sci. Soc. 82 : 87.

5. Ho, H. H., Zentmyer, G. A. and Erwin, D. C. (1977). Mycologia 69 : 641-646.

6. Julis, A. J., Clayton, C. N. and Sutton, T. B. (1978). Pl. Dis. Reptr. 62 : 516-520.

7. Katsura, K. (1971). Phytophthora diseases of plants, Seibundo-Shinkosha, Tokyo, pp. 1128 (in Japanese).

8. Masago, H., Yoshikawa, M., Fukada, M. and Nakanishi, N. (1977). Phytopathology 67 : $425-428$.

9. Mircetich, S. M., Matheron, M. E. and Tyler, R. H. (1976). Pro. Am. Phytop. Soc., $3: 229$.

10. Waterhouse, G. M. and Waterston, J. M. (1966). CMI descriptions of pathogenic fungi and bacteria, No. 112 .

11. Yanase, H., Sakuma, T. and Yamaguchi, A. (1976). Ann. Phytopath. Soc. Japan $42: 350-$ 351.

12. Zentmyer, G. A., Leary, J. V., Klure, L. J. and Grantham, G. L. (1976). Phytopathology $66: 982-986$. 
和 文 摘 要

Phytophthora cambivora (Petri) Buism. によるリンゴ

（矮性台木、MM 106）の疫病

\section{鈴井孝仁・星野好博}

1977年北海道余市地方のリンゴ矮性台木（MM 106）に collar rot 症状の発生が認められ，䍜病樹とその 附近の土袞から Phytophthora cambivora が多数分離された。分離菌株のうち150菌株は mating type $\mathrm{A}^{1}$ に属し, 9 菌株は mating type $\mathrm{A}^{2}$ であった。本菌はリンゴの幼木に病原性を示し, 本病の病原菌と考えら れた。本病を P c cactorum による病名と同じ疫病と呼称したい。

\section{Explanation of plate}

1 and 2. Symptoms of collar and root rot of dwarfing rootstock (MM 106) of apple caused by Phytophthora cambivora. 1. Diseased tree in orchard. 2. Upper part of layering is apple cv. starking delicious, and lower part is rootstock (MM 106).

3 and 4 . Sporangia of P. cambivora isolated from collar rot of apple. 3. Sporangium produced in proliferating sporangiophore. 4. Sporangium produced in monochasial sympodium.

5 and 6 . Oogonia with bullate protuberances and uni- and bi-cellular antheridia of $P$. $c a m b i$ vora when strain paired with an opposite strain. 5. Oogonium with protuberances. 6. Bi-cellular antheridium.

The scale represents $10 \mu \mathrm{m}$ in photographs $3,4,5$ and 6 . 

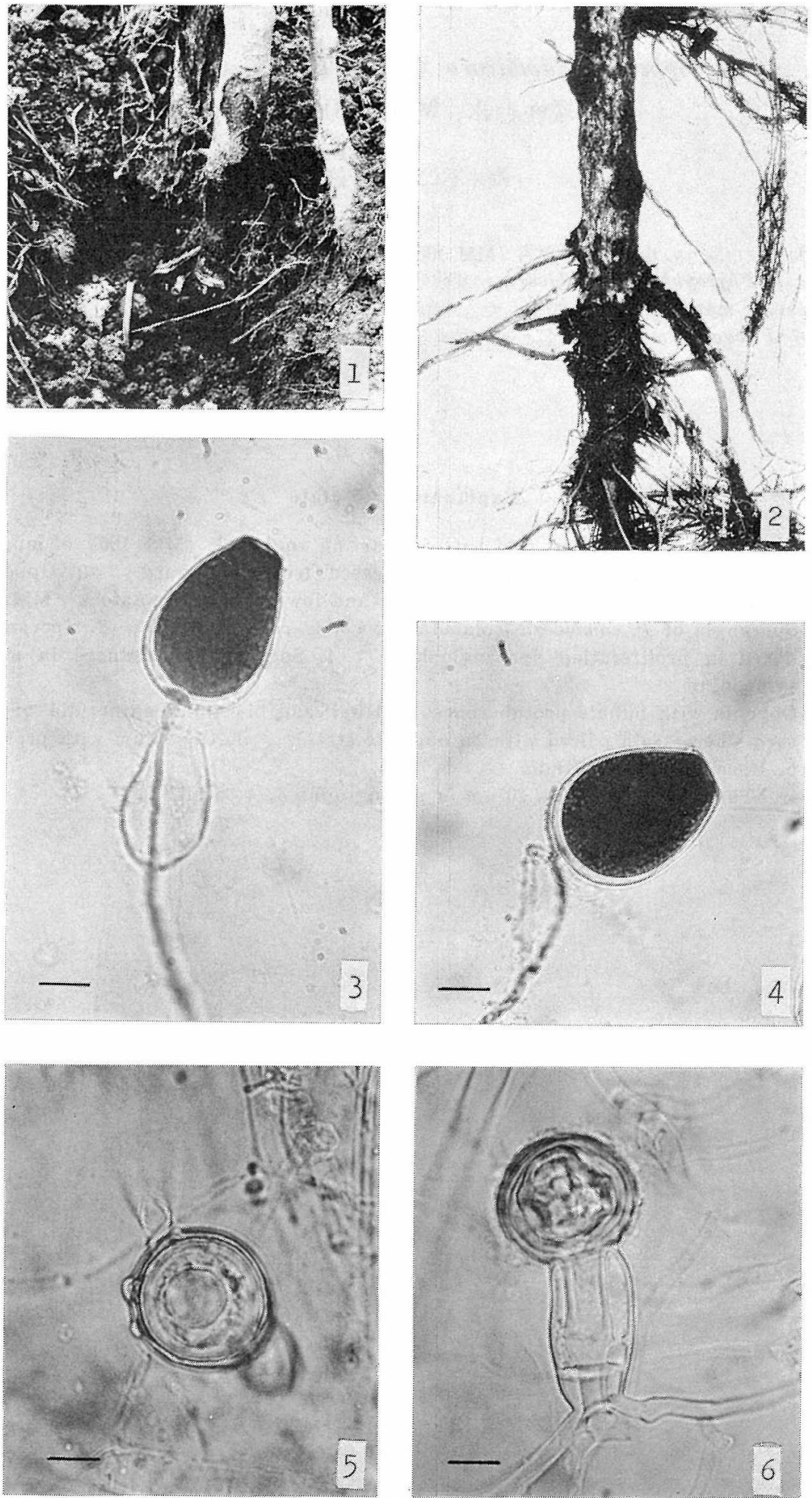